\title{
MENGGUNAKAN METODE DRP (DISTRIBUTION REQIREMENTS PLANNING) TERHADAP KEBUTUHAN MINYAK SOLAR DARI PENYALUR KE AGEN DAN SUB AGEN
}

\author{
Billy J. Camerling \\ Email: de bell89@yahoo.com \\ ${ }^{1)}$ Jurusan, Teknik Industri, Universitas Pattimura, Kampus Poka, Ambon, 97233, Indonesia \\ Dosen Program Studi Teknik Industri, Fakultas Teknik, Universitas Pattimura \\ e-mail : billicamerling@yahoo.co.id
}

\begin{abstract}
ABSTRAK
Suatu sistim distribusi yang baik perlu dilakukan untuk memenuhi permintaan konsumen melalui jalur distribusi yang ada.Sistim distribusi terpadu yaitu suatu sistim yang menangani distribusi mulai dari tingkat yang paling rendah sampai dengan ke pabrik atau perusahaan. Dengan mengunakan analisis DRP (Distribution Requirements Planning) dapat diketahui jedwal pengiriman minyak solar pada agen - agen dari distributor PT Linda baik pada agen-agen yang terdapat dalam level 2 dan level 1. Adapun jumlah yang harus dikirim untuk masing-masing agen antara lain ; agen Piru sebesar 273 kiloliter/tahun dengan 2 bulan per satu kali pengiriman, agen Kairatu sebesar 273 Kiloliter/tahun dengan 3 bulan per satu kali pengiriman, agen Saparua sebesar 1.613 Kiloliter/tahun dengan 2 bulan per satu kali pengiriman, agen Taniwel sebesar 612 Kiloloiter/tahun dengan 3 bulan per satu kali pengiriman.

Besar biaya distribusi selama periode perencanaan meliputi ; biaya Ordering Cost sebesar Rp. 12.409.153,-/tahun ; Biaya Holding Cost sebesar Rp.35.750.000.-/tahun. Dari analisa dengan mengunakan DRP maka dengan mengunakan jalur distribusi minyak solar yang diusulkan akan diperoleh biaya operasional sebesar Rp.159.524.420.- Per tahun. Dengan demikian maka akan terjadi pengehematan biaya operasional apabila perusahaan menggunakan jalur distribusi yang diusulkan, dengan besarnya biaya penghematan tersebut sebesar Rp.264.209.392,50 per tahun atau sebear 62,35\% per tahun.
\end{abstract}

Kata kunci : Peramalan, DRP, Penghematan biaya operasional.

\section{PENDAHULUAN}

Masalah pendistribusian suatu produk bagi suatu perusahaan merupakan salah satu masalah yang sangat penting.Dengan maksud bahwa semakin luas wilayah pemasaran, maka kendala yang dihadapai semakin banyak pula.Oleh karena itu perlu ada kebijakan-kebijakan khususnya tentang pembagian wilayah pemasaran pada masing-masing wilayah.Kebijakan ini membutuhkan penempatan persediaan pada setiap lokasi.Penyimpanan persediaan transit ini perlu ditangani dengan baik agar persedian yang ada dapat optimal, artinya dapat memenuhi tuntutan permintaan yang ada, tanpa harus melakukan penyimpanan yang berlebihan sehingga dapat menumpuk di gudang.Hal ini bisa menyebabkan tingginya biaya penyimpanan dan kemungkinan kerusakan yang terjadi semakin besar.

Suatu sistim distribusi yang baik perlu dilakukan untuk memenuhi permintaan konsumen melalui jalur distribusi yang ada.Sistim distribusi terpadu yaitu suatu sistim yang menangani distribusi mulai dari tingkat yang paling rendah sampai dengan ke pabrik atau perusahaan.Sistim ini menuntut suatu kesamaan dari tingkat yang paling rendah yaitu yang berhubungan langsung dengan konsumen (pemakai jasa) dan penyalur.Pada tingkat bawah, permintaan yang ada merupakan permintaan bebas (Independent Demand), karena langsung diperoleh dari konsumen, sedangkan untuk tingkat diatasnya (agen), permintaan yang ada merupakan akumulasi dari permintaan-permintaan dari penyalur dibawahnya.Jadi dapat dikatakan bahwa sistim ini mengandung logika tahapan waktu (Time Phase) yaitu urutan pemesanan dari bawah keatas berdasarkan tahapan waktu sehingga pada yang lebih atas sistim persediaan merupakan dependent demand karena bergantung pada tingkat dibawahnya, (Ballau. R. H. 1996). 
KAJIAN TEORI DAN METODE

Prinsip Dasar Distribution Requirements Planning (DRP)

Prinsip Dasar Distribution Requirements Planning (DRP) adalah penerapan sederhana dan murni dari penjadwalan MRP dan logika timephasing untuk manajemen distribusi. Prinsip ini pertama kali diterapkan tahun 1975 di Abbort Laboratories, Monteral Kanada.Meskipun konsep ini sering mengacu pada logika time-phasing tetapi baru tahun 1975 tersebut digunakan oleh industri untuk distribusi.Dengan pendekatan yang standar maka DRP diaplikasikan dalam pelaksanaan distribusi persediaan dan transportasi, baik pada perusahaan distribusi maupun manufaktoring, (Ballou, 1992).

Keuntungan Metode Distribution Requirements Palnning (DRP) dibandingkan Dengan Metode Pendistribusian Konvensional :(Ballau R. H. 1996)

1. Sistim ini mengandung logika tahapan waktu (Time Phase) yaitu urutan pemesanan dari bawah keatas berdasarkan tahapan waktu sehingga pada yang lebih atas sistim persediaan merupakan dependent demand karena bergantung pada tingkat dibawahnya. Sementara pada sistim distribusi konvensional setiap sistim terpisah-pisah dalam merencanakan kebutuhannya.

2. Sistim ini distribusi terpadu yaitu suatu sistim yang menangani distribusi mulai dari tingkat yang paling rendah sampai dengan ke pabrik atau perusahaan. Sistim ini menuntut suatu kesamaan dari tingkat yang paling rendah yaitu yang berhubungan langsung dengan konsumen (pemakai jasa) dan penyalur.

3. Sistim distribusi ini lebih banyak menerapkan sistim push yang lebih banyak mendorong terciptanya suatu mekanisme pendistribusian sesuai permintaan pasar dibandingkan dengan sistim pull yang lebih banyak menekankan pada keinginan pihak produsen untuk menyalurkan produknya tanpa melihat permintaan konsumen yang berfluktuasi setiap saat. Sistim pull ini umumnya dipakai pada isitim pendistribusian konvensional dan masih digunakan banyak sampai saat ini.
4. Dapat dikenali saling ketergantungan persediaan antara persediaan distribusi dan manufaktur

5. Sebuah jaringan distribusi yang lengkap dapat disusun, yang memberikan gambaran yang jelas dari atas maupun dari bawah jaringan.

6. DRP menyusun kerangka kerja untuk pengendalian logistikl total dari distribusi ke manufaktur untuk pembelian.

7. DRP menyediakan masukan untuk perencanaan transportasi dan penjadwalan dari sumber penawaran ke titik distribusi.

Asumsi-Asumsi Dalam Sistim Distribution Requirements Planning (DRP) (Ballau R. H. 1996)

1. Tidak dibenarkan adanya distribusi antar agen penjualan pada tingkat agen.

2. Distributor pada tingkat yang lebih rendah hanya memperoleh dari distributor level atas yang menjadi induknya

3. Permintaan yang terjadi pada agen, terminal berada pada kapasitas tanggung/tersedia.

\section{Logika Distribution Requirements Palnning (DRP)}

Dalam penggunaan DRP ada 4 macam logika dasar yang dipakai (Ballou, 1992) yaitu :

1.Hitung kapan persediaan on-hand dan in transit digunakan

2. Tentukan jumlah pemesanan yang dipasok dari pemakai sistim dan buat perencanaan pengiriman ke pusat distribusi.

3. Tentukan perencanaan waktu tunggu tanggal pengadaan dan hitung tanggal pengiriman untuk perencanaan pengiriman ke pusat distribusi.

4. Masukan perencanaan pengiriman ini dalam proyeksi perhitungan keseimbangan on-hand dan teruskan on-hand sampai akhir perencanaan biaya.

\section{PENERAPAN \\ DISTRIBUTIONREQUIREMENTS PLANNING (DRP)}

Ada beberapa penerapan dimana DRP biasa digunakan.Dan titik penanganan distribusi persediaan, DRP mempunyai penerapan umum tanpa banyak perubahan. Dalam manufaktur, dapat diterapkan untuk jenis produksi produksi make-to-stoke dan didistribusikan sebelum sampai konsumen, sebaliknya DRP tidak dapat diterapkan untuk jenis produksi make-to-order, 
yang dibuat berdasarkan pesanan dan langsung dikirimkan ke konsumen.

Pada gambar berikut ini digambarkan penerapan DRP untuk penjualan eceran, grosir dan lainnya.

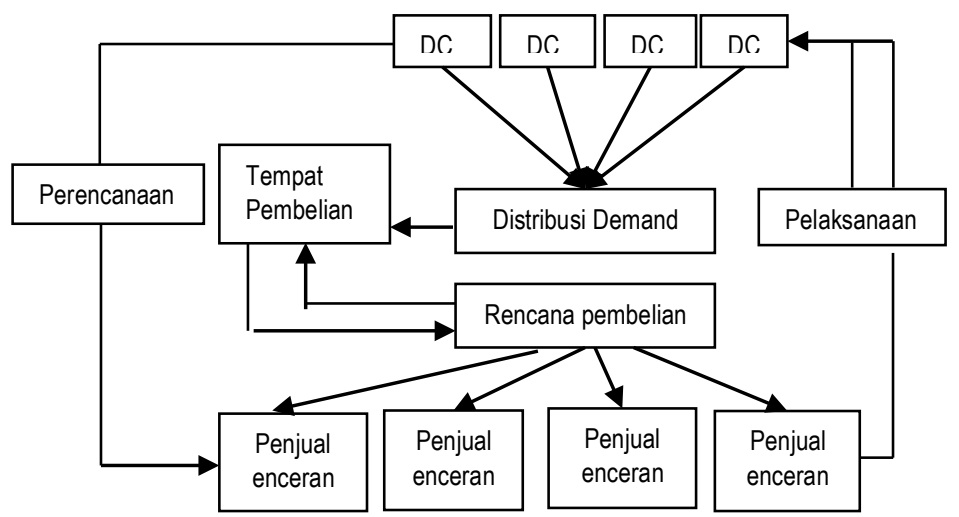

Gambar 1. Peranan DRP untuk penjualan enceran dan Grosil (Ballou, 1992).

\section{Analisis Distribution Requirements Planning (DRP)}

Analisa DRP dilakukan dengan menyususn komponen-komponen pembentuk DRP antara lain : informasi deskriptif, dan informasi time phase. Informasi deskriptif terdiri dari on hend balance, stock pemgaman, waktu tunggu dan EOQ (untuk waktu tunggu, on hend balance, stock pengaman dan waktu tunggu ). Langkah-langkah analisa (Ballou, 1992) adalah sebagai berikut :

a. Mengelompokan agen dan sub agen yang terdekat dengan wilayah pendistribusiannya, dan memagikanya menjadi level yang terbesar sampai pada level yang terkecil yang merupakan variabel dependent, kecuali level yang langsung memenuhi konsumen.

b. Dari hasil pemasaran dihitung time phased net requirement. Net requirement mengindikasikan kapan level persediaan dipenuhi oleh gross requirement untuk sebuah priode.

Net Requirement $=$ (gross requirement + Safety stock $)-($ schedule receipt + projected on hand periode sebelumnya). Nilai Net Requirement dicatat adalah nilai yang positif.

c. Setelah menghasilkan sebuah planned order receipt sejumlah net requirement tersebut (atau ukuran lot tertentu) pada suatu periode.

d. Ditentukan dari mana dilakukan pemesanan tersebut (planned order release, dengan mengunakan hari jadwalnya plannet order releas dengan laed time).

e. Dihitung Projected On Hand $(\mathrm{POH})$ pada periode tersebut. $\mathrm{POH}=(\mathrm{POH}$ Periode sebelumnya + Planned order release) - Gross Requirement.

\section{Prinsip-prinsip Penjadwalan}

Ada beberapa pringsip untuk melakukan penyusunan penjadwalan dan route pengiriman (Salim Abas 1993) antara lain :

a. Bebani alat angkut dengan total voluma pemberhetian yang jaraknya berdekatan satu sama lain. Rute yang terbentuk merupakan satu kelompok yang saling berdekatan satu sama lainnya.

b. Pemberhentian pada beberapa hari yang berbeda harus merencanakan dengan baik sebelumnya, agar dapat dihasilkan pengelompokan yang baik.

c. Pembentukan route sebaiknya dimulai dengan titik terjauh dari departemen yang bersangutan.

d. Urutan route yang efisien dari suatu perjalan hendaknya berbentuk kurva air mata sehingga dengan maksud agar tidak terjadi pengulangan route antara satu tujuan dengan tujuan yang lain, karena hal ini tersebut berarti pemborosan biaya.

e. Pembentukan route yang efisien adalah dengan mengunakan kendaraan yang terbesar yang tersedia.

f. Batas waktu pemberhentian yang sempit harus di hindari, karena hal ini dapat berakibatkan mengacaukan urutan penjadwalan.

Berdasarkan hasil perhitungan komputer dengan bantuan softwer MINITAB release 13 maka dengan mengunakan model Single Exponential Smoothing $\alpha=0,7$. diperoleh nilai error / galat yang lebih kecil untuk :

- level 2, Sub Agen Kawa, Pohon Batu, Rumakai, Kamariang ,Tuhaha, Nolot, Mornateng, Lisabata.

- level 1, Sub Agen Piru, Kairatu, Saparua, Taniwel

- level 0, PT LINDA 
Tabel 1. Komulatif Peningkatan Permintaan

Bahan Bakar Minyak Solaruntuk masingmasing sub agen

\begin{tabular}{|l|c|c|c|}
\hline $\begin{array}{l}\text { Nama Sub } \\
\text { Agen }\end{array}$ & $\begin{array}{c}\text { Hasil } \\
\text { Peramalan }\end{array}$ & $\begin{array}{c}\text { Permitaan } \\
\text { Aktual }\end{array}$ & $\begin{array}{c}\text { Peningkatan } \\
\text { Permintaan }\end{array}$ \\
\hline Kawa & 69.80 & 48.5 & 21.3 \\
\hline Pohon Batu & 67.04 & 38.0 & 30.04 \\
\hline Rumakai & 56.75 & 38.5 & 18.25 \\
\hline Kamariang & 56.42 & 37.0 & 19.42 \\
\hline Tuhaha & 39.72 & 29.5 & 10.23 \\
\hline Nolot & 39.83 & 27.0 & 12.83 \\
\hline Mornateng & 26.76 & 24.0 & 2.76 \\
\hline Lisabata & 28.35 & 23.0 & 5.35 \\
\hline Piru & 755.09 & 730.0 & 25.09 \\
\hline Kairatu & 150.50 & 150.0 & 0.50 \\
\hline Saparua & 2238.38 & 1870.0 & 368.38 \\
\hline Taniwel & 487.25 & 451.0 & 36.25 \\
\hline PT Linda & 4014.57 & 3398.5 & 616.07 \\
\hline
\end{tabular}

\section{Perhitungan EOQ Untuk Level 2}

Perhitungan EOQ untuk sub agen Kawa.

Diketahui :

Demand hasil ramalan $(D)=69,83$ Kiloliter

Berdasarkan data dari PT Linda maka :

Biaya Pemesanan $=$ Rp. $27.000 /$ satu kali pesan

Biaya Pengiriman $=$ Rp.520.833 /satu kali pesan

(Ordering Cost)k= Rp.547.833/satu kali pesan

Biaya Penyimpanan atau gudang = Biaya penyusutan tangki, dengan memperhitungkan variabel-variabel yang berpengaruh terhadap biaya penyusutan tangki adalah :

- Investasi atau harga beli tangki

- Umur pakai tangki

- Nilai sisa diasumsikan Nol

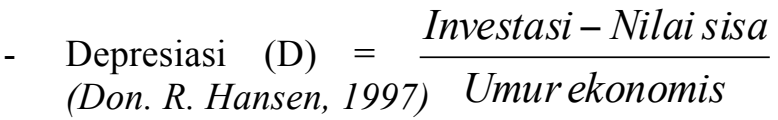

Diketahui :

- Investasi = Rp. 3.000 .000 (sub agen Kawa)

- Nilai sisa $=$ Rp. 0

- Umur Ekonomis = 20 tahun

Sehingga ;

- $\quad \mathrm{D}=\frac{3.000 .000-0}{20}=$ Rp. $150.000 /$ tahun

(holding Cost) $\mathrm{h}=\mathrm{Rp} .150 .000 /$ tahun

Maka perhitungan persediaan unsuk sub agen

Kawa adalah sebagai berikut :

a. Ukuran Pemesanan Ekonomis (EOQ) =

$$
\sqrt{\frac{2 . \mathrm{D} . \mathrm{k}}{\mathrm{h}}}=\sqrt{\frac{2.69,83 \cdot 547 \cdot 833}{150.000}}=\sqrt{510,069}
$$

$=22,58$ kiloliter $\approx 23$ kiloliter
Frekuensi pemesanan (f) $=\frac{69,83}{23}=3,04$ kali $\approx$

3 kali pesan /tahun

Lama waktu antar pemesan optimal (t)

$=\frac{\mathrm{EOQ}}{\mathrm{D}}=\frac{23}{69,83}=0,329$ tahun

b. Diketahui lead time / tenggang waktu pemesanan $(\mathrm{L})=12$ hari $\approx 2$ minggu

Kebutuhan per tahun $=69,83$ kiloliter

$\begin{gathered}\text { Kebutuhan rata-rata per bulan } \\ =4,65 \text { kiloliter/bulan }\end{gathered}=\frac{69.83 \text { Kiloliter }}{15 \text { bulan }}$ Kebutuhan selama lead time $=1 / 2 \times 4,65$ kiloliter $=2,325$ kiloliter $/$ minggu

Reorder point $(\mathrm{R})=\mathrm{L} \times \mathrm{D}_{\mathrm{L}}=2$ minggu $\times 2,325$ kiloliter $/$ minggu $=4,65$ kiloliter

c. TIC (Total Incremental Cost) / Biaya total persediaan

TIC $=\sqrt{2 . D \cdot k \cdot h}$

$=\sqrt{2 \times 69,83 \times 547.833 \times 150.000}$

$=$ Rp.3.387.706,23 Rp. 3.387.706

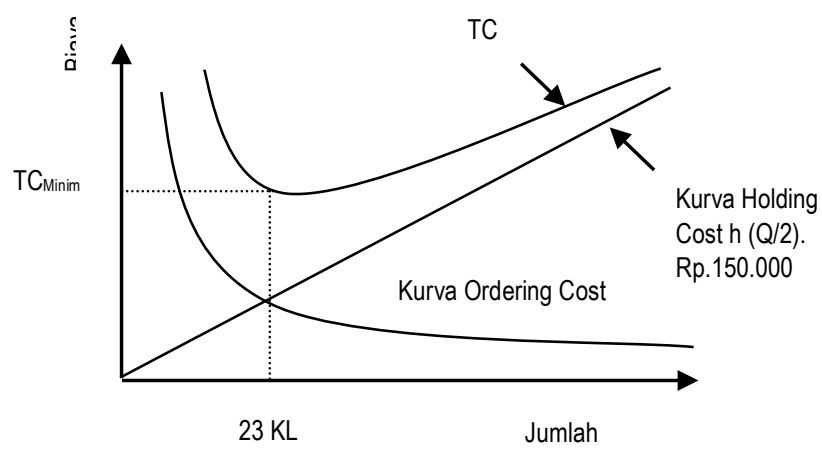

Gambar 2.Posisi titik EOQ yang membentuk TC Minimum

Dengan memperhitungkan kondisi keamanan maka leat time (tenggang waktu) yang ideal untuk kedatangan bahan bakar minyak solar jika terjadi keterlambatan 2 minggu, dengan kondisi $\mathrm{L}>\mathrm{t}$ secara grafik hasil perhitungan diatas digambarkan sebagai berikut : 
Tingkat

Persediaan

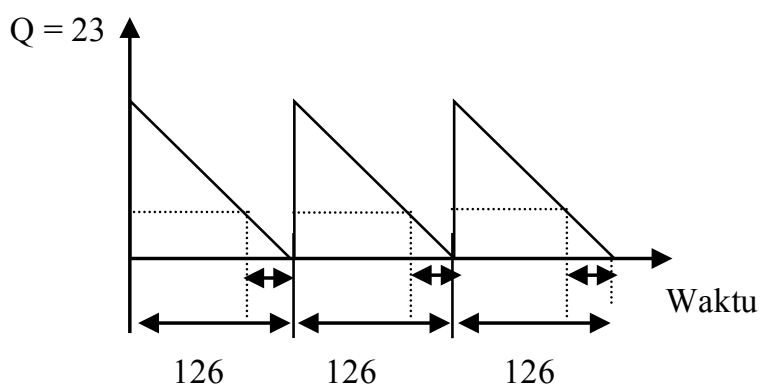

Gambar 3. Tingkat persediaan EOQ terhadap Waktu

Hasil perhitungan persediaan selengkapnya untuk setiap level 2, level 1, dan level 0 dapat dilihat pada table dibawah ini :
Tabel 2. Perhitungan Persediaan Setiap Level

\begin{tabular}{|c|c|c|c|c|c|c|}
\hline & & $\begin{array}{l}\text { Ukuran } \\
\text { pemesan } \\
\text { an } \\
\text { ekonomi } \\
\text { s }\end{array}$ & $\begin{array}{l}\text { Titik } \\
\text { pemesa } \\
\text { nan } \\
\text { kembali }\end{array}$ & $\begin{array}{l}\text { Waktu } \\
\text { antar } \\
\text { pemesa } \\
\text { nan } \\
\text { optimu } \\
\text { m }\end{array}$ & $\begin{array}{l}\text { Le } \\
\text { ad } \\
\text { tim } \\
\text { e }\end{array}$ & $\begin{array}{l}\text { Biaya } \\
\text { total } \\
\text { persedi } \\
\text { aan }\end{array}$ \\
\hline & & liter & liter & hari & $\begin{array}{l}\text { ha } \\
\text { ri }\end{array}$ & rupiah \\
\hline \multirow{8}{*}{$\begin{array}{l}\text { Level } \\
2\end{array}$} & Kawa & 23.000 & 4650 & 126 & 12 & $\begin{array}{l}3.378 . \\
706\end{array}$ \\
\hline & $\begin{array}{l}\text { Pohon } \\
\text { batu }\end{array}$ & 22.000 & 4469 & 126 & 12 & $\begin{array}{l}3.331 . \\
940\end{array}$ \\
\hline & $\begin{array}{l}\text { Rumak } \\
\text { ai }\end{array}$ & 22.000 & 4469 & 126 & 12 & $\begin{array}{l}3.331 . \\
940\end{array}$ \\
\hline & $\begin{array}{l}\text { Kamari } \\
\text { an }\end{array}$ & 18.000 & 3761 & 119 & 12 & $\begin{array}{l}2.735 . \\
195\end{array}$ \\
\hline & $\begin{array}{l}\text { Tuhah } \\
\text { a }\end{array}$ & 17.000 & 2649 & 154 & 12 & $\begin{array}{l}2.565 . \\
012\end{array}$ \\
\hline & Nolot & 16.000 & 2655 & 112 & 12 & $\begin{array}{l}2.433 . \\
874\end{array}$ \\
\hline & $\begin{array}{l}\text { Mornate } \\
\text { ng }\end{array}$ & 15.000 & 1984 & 182 & 12 & $\begin{array}{l}2.431 .11 \\
8\end{array}$ \\
\hline & $\begin{array}{l}\text { Lisabat } \\
\text { a }\end{array}$ & 15.000 & 1890 & 189 & 12 & $\begin{array}{l}2.431 . \\
118\end{array}$ \\
\hline \multirow{3}{*}{$\begin{array}{c}\text { Level } \\
1\end{array}$} & Pिiru & 91.000 & 5034 & 56 & 12 & $\begin{array}{l}22.459 .5 \\
26\end{array}$ \\
\hline & Kairatu & 33.000 & 1003 & 56 & 12 & $\begin{array}{l}6.585 . \\
262\end{array}$ \\
\hline & $\begin{array}{l}\text { Saparu } \\
\text { a }\end{array}$ & 185.000 & 1492 & 42 & 12 & $\begin{array}{l}9.925 . \\
952\end{array}$ \\
\hline $\begin{array}{l}\text { Level } \\
0\end{array}$ & $\begin{array}{l}\text { PT } \\
\text { Linda } \\
\text { Ambon }\end{array}$ & 337.000 & $\begin{array}{l}269.40 \\
0\end{array}$ & 42 & 12 & $\begin{array}{l}908.72 \\
6.409\end{array}$ \\
\hline
\end{tabular}

Analisis biaya biaya persediaan untuk masingmasing Level

Berdasarkan perhitungan diatas, maka jika PT Linda mencoba menerapkan perhitungan tersebut maka akan diperoleh penghematan biaya persediaan sebesar :

Total biaya persediaan bahan bakar minyak solar pada sub agen Kawa adalah :

(Holding Cost + Ordering Cost) $x$ Frekuensi Pemesanan

$$
\begin{aligned}
& =(\text { Rp. } 150.000+547.833) \times 12 \\
& =\text { Rp.8.373.996 }
\end{aligned}
$$

Sehingga penghematan yang terjadi pada biaya persediaan bahan bakar minyak solar adalah ; Rp.8.373.996 - Rp.3.387.706 = Rp.4.986.290.Presentase penghematan biaya peresediaan 


$$
=100 \%-\left(\frac{R p \cdot 3 \cdot 387.706}{R p \cdot 4 \cdot 986.290}\right) \times 100 \%
$$

$=32,06 \%$

Selanjutnya hasil perhitungan analisis biaya persediaan untuk masing-masing sug agen, agen dan distributor dapat dilihat pada tabel berikut : gross requirment, intransit,project on

hend,planned order shipping.

Pengolahan Data DRP untuk level 1, 2 dan 0 Tabel 4. Pembentukan DRP Level 2 sub agen Kawa

$\begin{array}{llllll}\text { On Hand } & : & 0 & \text { Lead } & : & 12 \\ \text { Balance } & & & \text { Time } & & \\ \text { Safety } & : & 0 & \text { EO } & : & 22 \\ \text { Stock } & & & 0 & & \end{array}$

Tabel 3. Hasil komulatif analisis biaya persedian (TIC)

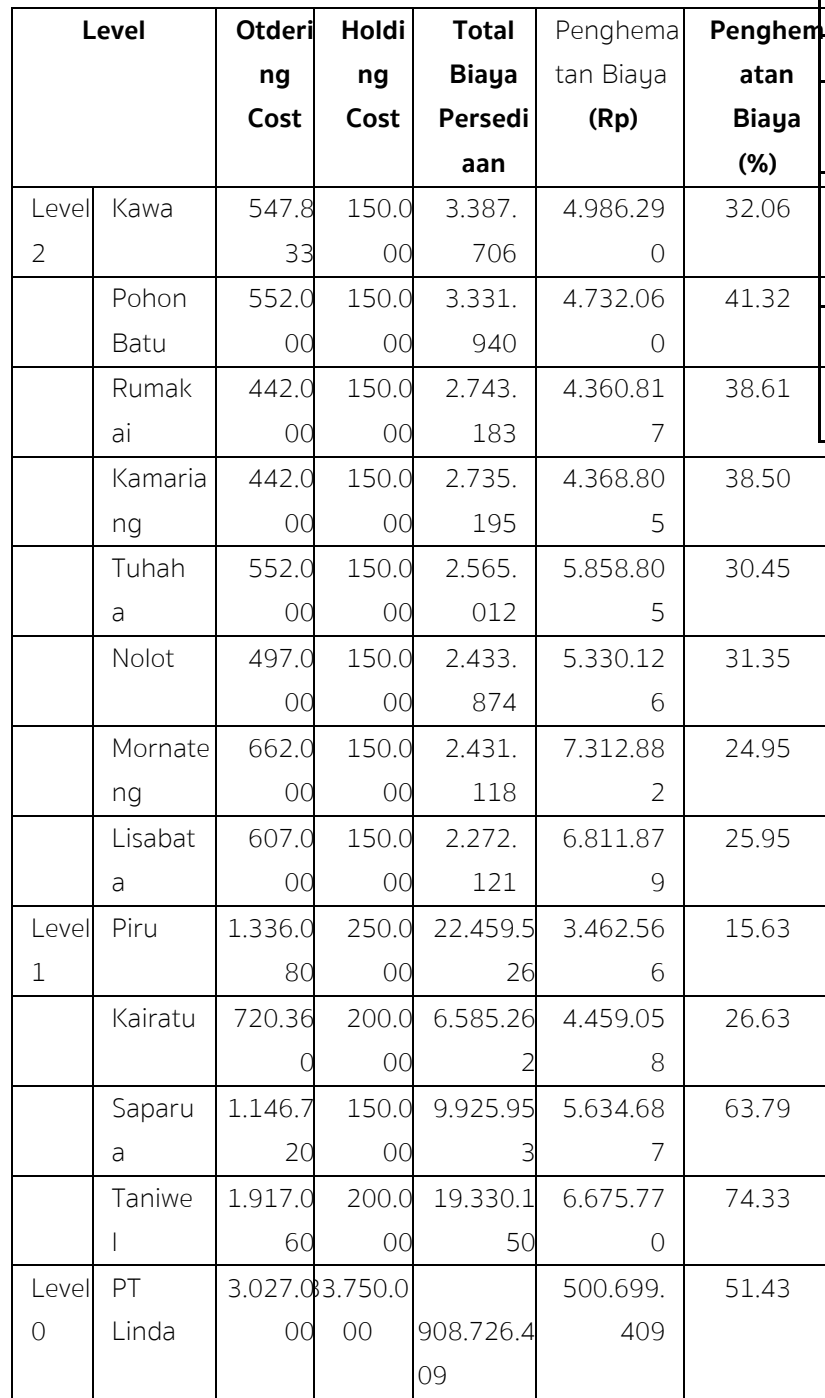

\section{Pembentukan Distribution Reqirements Planning (DRP)}

Pembentukan DRP dilakukan dengan menyusun komponen pembentukan DRP, yaitu informasi denkriptif dan informasi time phase. Informasi Denkriptif meliputi : on hend balance,stock pengaman,waktu tunggu,dan EOQ yang sudah di jelaskan didepan Informasi Time Phase meliputi :

\begin{tabular}{|c|c|c|c|c|c|c|c|c|c|c|c|c|c|c|}
\hline Bulan & 1 & 2 & 3 & 4 & 5 & 6 & 7 & 8 & 10 & 10 & $11 \mid 1$. & $12 \mid 13$ & \begin{tabular}{l|l|}
3 & 14 \\
\end{tabular} & 15 \\
\hline Gross & 4.6 & 4.6 & 4.6 & \begin{tabular}{|l|}
4.6 \\
\end{tabular} & \begin{tabular}{l|l}
4.6 & 2 \\
\end{tabular} & \begin{tabular}{l|l}
4.6 & 4. \\
\end{tabular} & \begin{tabular}{l|l}
4.6 & 4.
\end{tabular} & \begin{tabular}{l|l}
4.6 & 4.
\end{tabular} & \begin{tabular}{l|l}
6 & 4.
\end{tabular} & \begin{tabular}{l|l}
4.6 & 4.
\end{tabular} & \begin{tabular}{l|l}
4.6 & 4.
\end{tabular} & \begin{tabular}{l|l}
4.6 & 4.6 \\
\end{tabular} & \begin{tabular}{|l|l|}
6 & 4.6 \\
\end{tabular} & 4.6 \\
\hline Requirement & 5 & 5 & 5 & 5 & 5 & 5 & 5 & 5 & 5 & 5 & 5 & 5 & 5 & 5 \\
\hline ntransit & 22 & & & & & & & & & & & & & \\
\hline Projected On & $\begin{array}{ll}0 & 17 .\end{array}$ & 12. & 8.0 & 3.4 & 20.1 & 16. 1 & 11. 6 . & \begin{tabular}{l|l}
6.8 & 2.
\end{tabular} & \begin{tabular}{l|l}
.1 & 19
\end{tabular} & 9.12 & 14. 10 & 10. 5.5 & 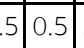 & 18. \\
\hline Hand & 4 & 7 & 5 & 0 & 8 & 15 & 5 & & $5 \mid 5$ & $5 \mid 9$ & 9 & $2 \quad 5$ & 5 & 3 \\
\hline $\begin{array}{l}\text { Planned } \\
\text { Prder } \\
\text { Reccived }\end{array}$ & & & & & 22 & & & & & 22 & & & & 22 \\
\hline $\begin{array}{l}\text { Planned } \\
\text { prder } \\
\text { \$hipping }\end{array}$ & & & & 22 & & & & & 22 & & & & 22 & \\
\hline
\end{tabular}

Tabel 5. Pembentukan DRP Level 2 sub agen Pohon Batu

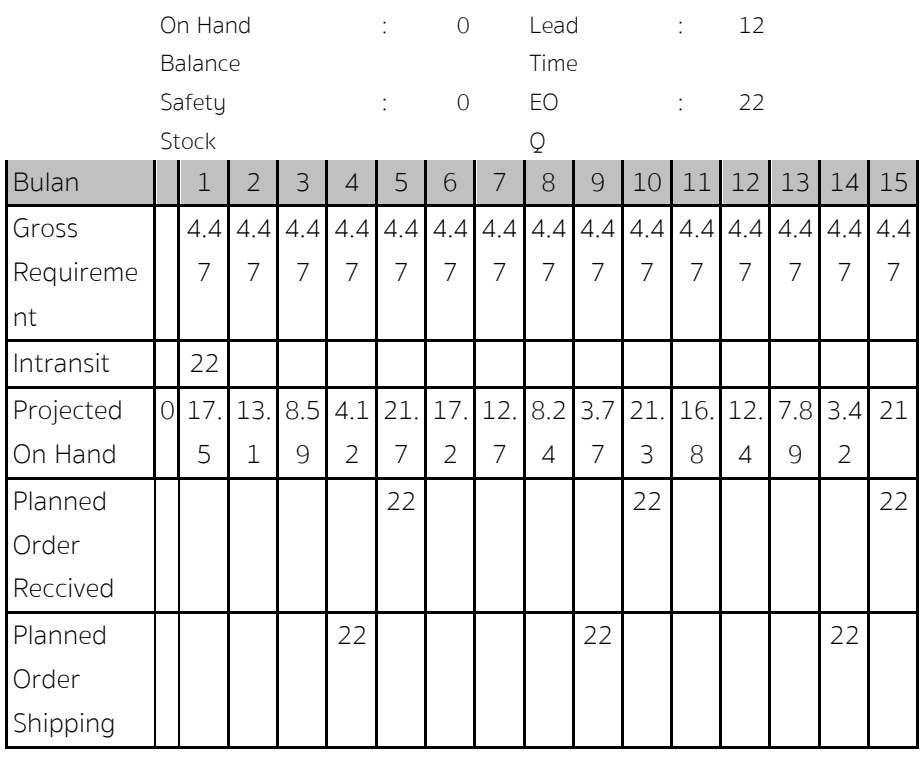

Tabel 6. Pembentukan DRP Level 2 sub agen Rumakai

$\begin{array}{llllll}\text { On Hand } & : & 0 & \text { Lead } & : & 12 \\ \text { Balance } & & & \text { Time } & & \\ \text { Safety } & : & 0 & \text { EO } & : & 18 \\ \text { Stock } & & & 9 & & \end{array}$

\begin{tabular}{|l|c|c|c|c|c|c|c|c|c|c|c|c|c|c|c|c|} 
Bulan & 1 & 2 & 3 & 4 & 5 & 6 & 7 & 8 & 9 & 10 & 11 & 12 & 13 & 14 & 15 \\
\hline Gross & 3.7 & 3.7 & 3.7 & 3.7 & 3.7 & 3.7 & 3.7 & 3.7 & 3.7 & 3.7 & 3.7 & 3.7 & 3.7 & 3.7 & 3.7 \\
Requireme & 8 & 8 & 8 & 8 & 8 & 8 & 8 & 8 & 8 & 8 & 8 & 8 & 8 & 8 & 8 \\
nt & & & & & & & & & & & & & & & \\
\hline Intransit & 18 & & & & & & & & & & & & & & \\
\hline Projected & 0 & 14. & 10. & 6.6 & 2.8 & 17. & 13. & 9.5 & 5.7 & 1.9 & 16. & 12. & 8.6 & 4.8 & 1.0 & 15. \\
\hline
\end{tabular}




\begin{tabular}{|l|l|l|l|l|l|l|l|l|l|l|l|l|l|l|l|l|l|}
\hline On Hand & 2 & 4 & 6 & 8 & 1 & 3 & 4 & 6 & 8 & 2 & 4 & 4 & 6 & 8 & 3 & Prder \\
\hline $\begin{array}{l}\text { Planned } \\
\text { Order } \\
\text { Reccived }\end{array}$ & & & & & 18 & & & & & 18 & & & & & 1 19 phipp \\
\hline $\begin{array}{l}\text { Planned } \\
\text { Order } \\
\text { Shipping }\end{array}$ & & & & & 18 & & & & & 18 & & & & & 18 & \\
\hline
\end{tabular}

Tabel 7. Pembentukan DRP Level 2 sub agen Kamariang

$\begin{array}{llllll}\text { On Hand } & : & 0 & \text { Lead } & : & 12 \\ \text { Balance } & & & \text { Time } & & \\ \text { Safety } & : & 0 & \text { EO } & : & 18 \\ \text { Stock } & & & 0 & & \end{array}$

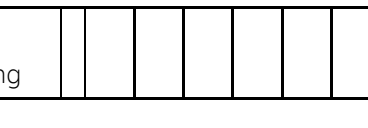

Tabel 9. Pembentukan DRP Level 2 sub agen Nolot

$\begin{array}{lllll}\text { On Hand } & : & 0 & \text { Lead } & : \\ \text { Balance } & & \text { Time }\end{array}$

Safety

$0 \quad$ EO

16

Stock

\begin{tabular}{|l|c|c|c|c|c|c|c|c|c|c|c|c|c|c|c|c|} 
Bulan & 1 & 2 & 3 & 4 & 5 & 6 & 7 & 8 & 9 & 10 & 11 & 12 & 13 & 14 & 15 \\
\hline Gross & 2.6 & 2.6 & 2.6 & 2.6 & 2.6 & 2.6 & 2.6 & 2.6 & 2.6 & 2.6 & 2.6 & 2.6 & 2.6 & 2.6 & 2.6 \\
Requirement & 5 & 5 & 5 & 5 & 5 & 5 & 5 & 5 & 5 & 5 & 5 & 5 & 5 & 5 & 5 \\
\hline Intransit & 16 & & & & & & & & & & & & & & \\
\hline
\end{tabular}

\begin{tabular}{|c|c|c|c|c|c|c|c|c|c|c|c|c|c|c|c|c|c|c|c|c|c|c|c|c|c|c|c|c|c|}
\hline Bulan & 1 & 2 & 3 & 4 & 5 & 6 & 7 & 8 & 9 & 10 & 11 & 12 & 13 & 14 & $1 \$$ pojected On & 013. & 10. & 8.0 & 5.3 & $2.7 \mid$ & 0.0 & 13. 1 & 10. 8 & \begin{tabular}{l|l}
8.0 & 5.
\end{tabular} & \begin{tabular}{l|l}
5.4 & 2.7
\end{tabular} & 0.0 & 13. & 10. & 8.1 \\
\hline Gross & 3.7 & 3.7 & 3.7 & 3.7 & 3.7 & 3.7 & 3.7 & 3.7 & 3.7 & $3.7 \mid=$ & 3.7 & 3.7 & 3.7 & 3.7 & 3 Fland & 3 & 7 & 2 & 6 & & 4 & 4 & 7 & 6 & 4 & 8 & 4 & 8 & \\
\hline $\begin{array}{l}\text { Requireme } \\
\text { nt }\end{array}$ & 6 & 6 & 6 & 6 & 6 & 6 & 6 & 6 & 6 & 6 & 6 & 6 & 6 & 6 & $\begin{array}{l}\$ p \\
\text { onned }\end{array}$ & & & & & & & 16 & & & & & 16 & & \\
\hline Intransit & 18 & & & & & & & & & & & & & & Reccived & & & & & & & & & & & & & & \\
\hline Projected & 0.15. & 10. & 6.7 & 3.0 & 17. & 13. & 9.7 & 5.9 & 2.2 & 16. & 12. & 8.9 & 5.1 & 1.4 & 1p. anned & & & & & & 16 & & & & & 16 & & & \\
\hline On Hand & 2 & 5 & & & 2 & 4 & & & & 4 & 6 & & & & $\$$ фorder & & & & & & & & & & & & & & \\
\hline Planned & & & & & 18 & & & & & 18 & & & & & 1 \$hipping & & & & & & & & & & & & & & \\
\hline
\end{tabular}

Order

Reccived

Planned

Order

Shipping

Tabel 10. Pembentukan DRP Level 2 sub agen Mornateng

\section{Tabel 8. Pembentukan DRP Level 2 sub agen Tuhaha}

$\begin{array}{llllll}\text { On Hand } & : & 0 & \text { Lead } & : & 12 \\ \text { Balance } & & & \text { Time } & & \\ \text { Safety } & : & 0 & \text { EO } & : & 15 \\ \text { Stock } & & & 9 & & \end{array}$

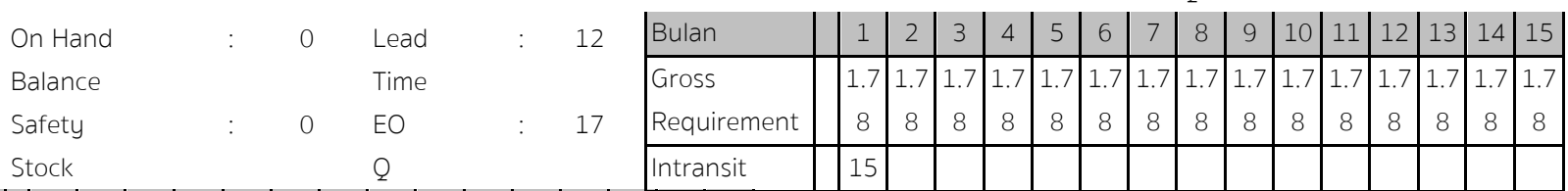

\begin{tabular}{|c|c|c|c|c|c|c|c|c|c|c|c|c|c|c|c|c|c|c|c|c|c|c|c|c|c|c|c|c|c|c|}
\hline Bulan & 1 & 2 & 3 & 4 & 5 & 6 & 7 & 8 & 9 & $10 \mid$ & 11 & $|12|$ & 1 非 & piof dited & \multirow{2}{*}{ On } & \multirow{2}{*}{$0 \mid \begin{array}{c}13 . \\
2\end{array}$} & \multirow{2}{*}{\begin{tabular}{|c|}
11. \\
4
\end{tabular}} & \multirow{2}{*}{\begin{tabular}{|c|}
9.6 \\
6
\end{tabular}} & \multirow{2}{*}{$\begin{array}{c}7.8 \\
8\end{array}$} & \multirow{2}{*}{6.1} & \multirow{2}{*}{\begin{tabular}{|c|}
4.3 \\
2
\end{tabular}} & \multirow{2}{*}{\begin{tabular}{|c|}
2.5 \\
4
\end{tabular}} & \multirow{2}{*}{\begin{tabular}{|c|}
0.7 \\
6
\end{tabular}} & \multirow{2}{*}{14} & \multirow{2}{*}{$\begin{array}{c}12 . \\
2\end{array}$} & \multirow{2}{*}{\begin{tabular}{|c|}
10. \\
4
\end{tabular}} & \multirow{2}{*}{\begin{tabular}{c|}
8.6 \\
4
\end{tabular}} & \multirow{2}{*}{\begin{tabular}{|c|}
6.8 \\
6
\end{tabular}} & \multirow{2}{*}{\begin{tabular}{c|c}
5.0 & 3. \\
8 &
\end{tabular}} & \multirow[t]{2}{*}{3.3} \\
\hline Gross & 2.6 & 2.6 & 2.6 & 2.6 & 2.6 & 2.6 & 2.6 & 2.6 & 2.6 & \begin{tabular}{l|l}
2.6 & 2
\end{tabular} & \begin{tabular}{l|l}
2.6 & 2
\end{tabular} & 2.6 & 2. $\phi$ & 的, 6412.6 & & & & & & & & & & & & & & & & \\
\hline $\begin{array}{l}\text { Requireme } \\
\mathrm{nt}\end{array}$ & 6 & 6 & 6 & 6 & 6 & 6 & 6 & 6 & 6 & 6 & 6 & 6 & $6 \longdiv { p }$ & $\begin{array}{l}\text { Piantieged } \\
\text { prder }\end{array}$ & & & & & & & & & & 15 & & & & & & \\
\hline Intransit & 17 & & & & & & & & & & & & & Recdived & & & & & & & & & & & & & & & & \\
\hline Projected & 14. & 11. & 9.0 & 6.4 & 3.7 & 1.1 & 15. & 12. & 10. 7 & 7.5 & 4.82 & 2.2 & 16 . & plazingd. & & & & & & & & & 15 & & & & & & & \\
\hline On Hand & 4 & 7 & 5 & & 5 & & 5 & 8 & 2 & & 5 & & 6 & predter 3 & & & & & & & & & & & & & & & & \\
\hline Planned & & & & & & & 17 & & & & & & 1䒠 & phipping & & & & & & & & & & & & & & & & \\
\hline Order & & & & & & & & & & & & & & & & & & & & & & & & & & & & & & \\
\hline Reccived & & & & & & & & & & & & & & & & & & & & & & 1. & el 25 & & & & & pata & & \\
\hline Planned & & & & & & 17 & & & & & & 17 & & & & & & & & & & & & & & & & & & \\
\hline
\end{tabular}

Fakultas Teknik Universitas Pattimura, 


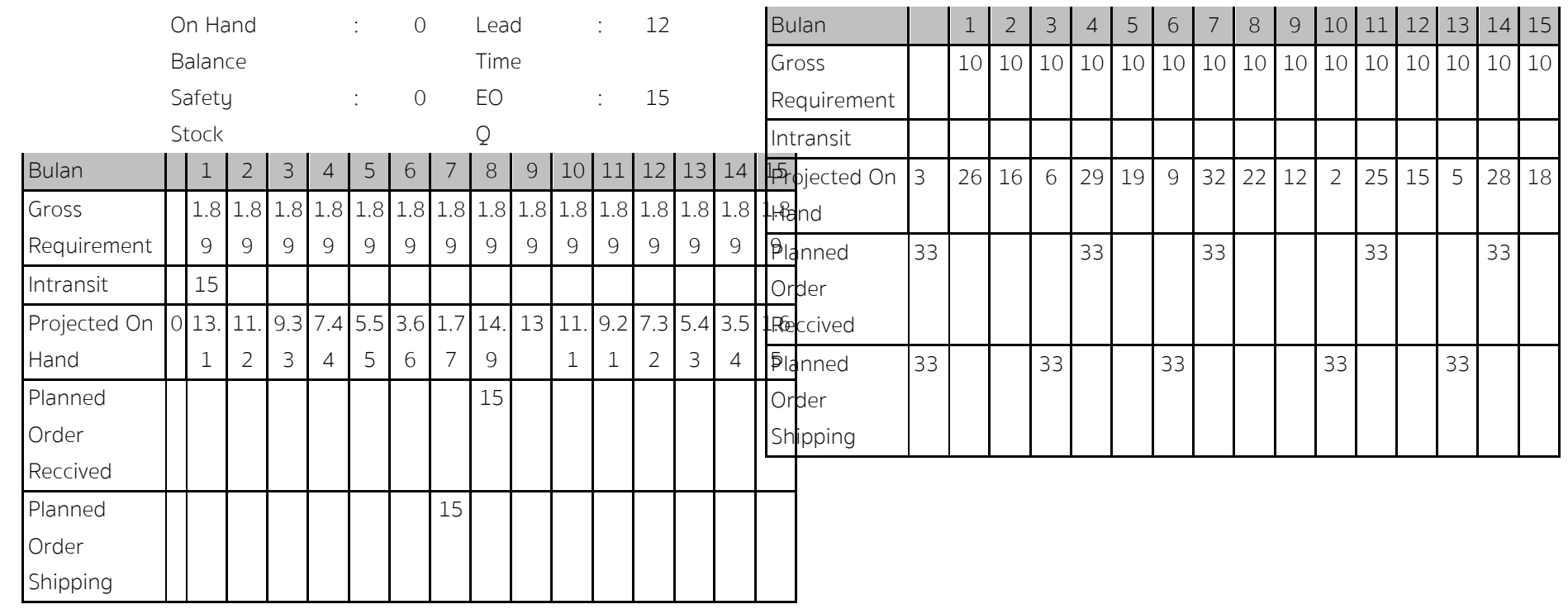

Tabel 14. Pembentukan DRP Level 1 agen Saparua

$\begin{array}{llllll}\text { On Hand Balance } & : & 20 & \begin{array}{l}\text { Lead } \\ \text { Time }\end{array} & \text { : } & 12 \\ \text { Safety Stock } & : & 0 & \text { EO } & : & 18\end{array}$

Tabel 12. Pembentukan DRP Level 1 agen Piru

\begin{tabular}{|c|c|c|c|}
\hline \multirow[t]{2}{*}{ On Hand } & : & 8 & Lead \\
\hline & & & Time \\
\hline Safety & : & 0 & EO \\
\hline Stock & & & $Q$ \\
\hline
\end{tabular}

\begin{tabular}{|c|c|c|c|c|c|c|c|c|c|c|c|c|c|c|c|}
\hline Bulan & 1 & 2 & 3 & 4 & 5 & 6 & 7 & 8 & 9 & 10 & 11 & 12 & 13 & 14 & $1 !$ \\
\hline Gross & 14 & 14 & 14 & 14 & 14 & 14 & 14 & 14 & 14 & 14 & 14 & 14 & 14 & 149. & 14 \\
\hline Requireme & 9. & 9. & 9. & 9. & 9. & 9. & 9. & 9. & 9. & 9. & 9. & 9. & 9. & & 9 \\
\hline$n t$ & & & & & & & & & & & & & & & \\
\hline Intransit & & & & & & & & & & & & & & & \\
\hline
\end{tabular}

\begin{tabular}{|c|c|c|c|c|c|c|c|c|c|c|c|c|c|c|c|}
\hline Bulan & & 1 & 2 & 3 & 4 & 5 & 6 & 7 & 8 & 9 & 10 & 11 & 12 & 13 & 14 \\
\hline Gross & & 50. & 50. & 50. & 50. & 50. & 50. & 50. & 50. & 50. & 50. & 50. & 50. & 50. & 50. \\
\hline Requirement & & 3 & 3 & 3 & 3 & 3 & 3 & 3 & 3 & 3 & 3 & 3 & 3 & 3 & 3 \\
\hline \multicolumn{16}{|l|}{ Intransit } \\
\hline Projected On & 8 & 48. & 89. & 38. & 79. & 29. & 69. & 19. & 60. & 9.9 & 50. & 0.2 & 40. & 81. & 31. \\
\hline Hand & & 6 & 3 & 9 & 6 & 3 & 9 & 6 & 2 & & 6 & & 9 & 5 & 2 \\
\hline Planned & 91 & 91 & & & 91 & & 91 & & 91 & & 91 & & 91 & & \\
\hline Order & & & & & & & & & & & & & & & \\
\hline Reccived & & & & & & & & & & & & & & & \\
\hline Planned & 91 & 91 & & 91 & & 91 & & 91 & & 91 & & 91 & & & 91 \\
\hline Order & & & & & & & & & & & & & & & \\
\hline Shipping & & & & & & & & & & & & & & & \\
\hline
\end{tabular}

Ifspjected

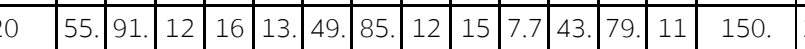

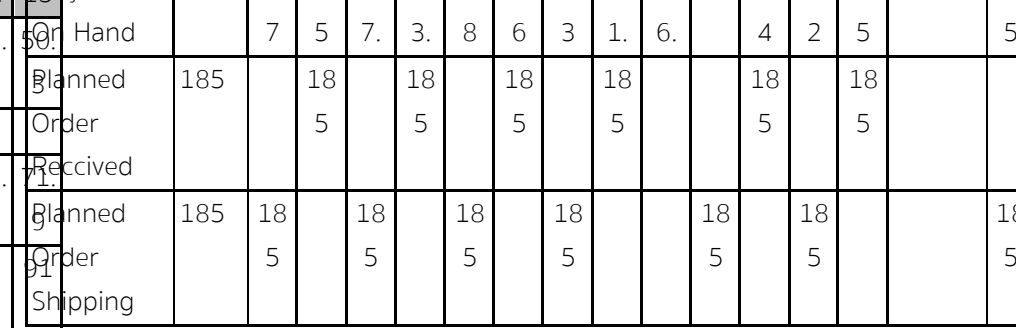

Tabel 13. Pembentukan DRP Level 1 agen Kairatu

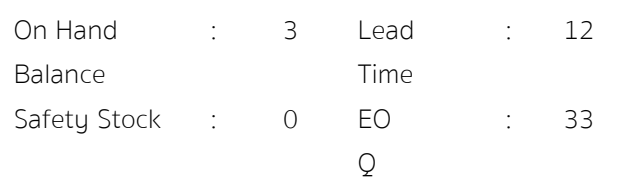

\section{Tabel 15. Pembentukan DRP Level 1 agen Taniwel}

$\begin{array}{llllll}\text { On Hand } & : & 6 & \text { Lead } & : & 12 \\ \text { Balance } & & & \text { Time } & & \\ \text { Safety } & : & 0 & \text { EO } & : & 97 \\ \text { Stock } & & & \text { Q } & & \end{array}$

\begin{tabular}{|l|c|c|c|c|c|c|c|c|c|c|c|c|c|c|c|c|} 
Bulan & & 1 & 2 & 3 & 4 & 5 & 6 & 7 & 8 & 9 & 10 & 11 & 12 & 13 & 14 & 15 \\
\hline Gross & & 32 & 32. & 32 & 32 & 32. & 32. & 32. & 32 & 32 & 32. & 32. & 32. & 32 & 32. & 32. \\
Requireme & & 5 & 5 & 5 & 5 & 5 & 5 & 5 & 5 & 5 & 5 & 5 & 5 & 5 & 5 & 5 \\
nt & & & & & & & & & & & & & & & & \\
\hline
\end{tabular}




\begin{tabular}{|l|l|l|l|l|l|l|l|l|l|l|l|l|l|l|l|l|}
\hline Intransit & & & & & & & & & & & & & & & & \\
\hline $\begin{array}{l}\text { Projected } \\
\text { On Hand }\end{array}$ & 6 & 70. & 38 & 5.5 & 70 & 37. & 5.0 & 69 & 37 & 4.5 & 69 & 36. & 4.0 & 68. & 36 & 3.5 \\
\hline $\begin{array}{l}\text { Planned } \\
\text { Order } \\
\text { Reccived }\end{array}$ & 97 & & & & 97 & & & 97 & & & 97 & & & 97 & & \\
\hline $\begin{array}{l}\text { Planned } \\
\text { Order } \\
\text { Shipping }\end{array}$ & 97 & & & 97 & & & 97 & & & 97 & & & 97 & & & 97 \\
\hline
\end{tabular}

Tabel 17. Pembentukan DRP Level 0 Distributor PT Linda

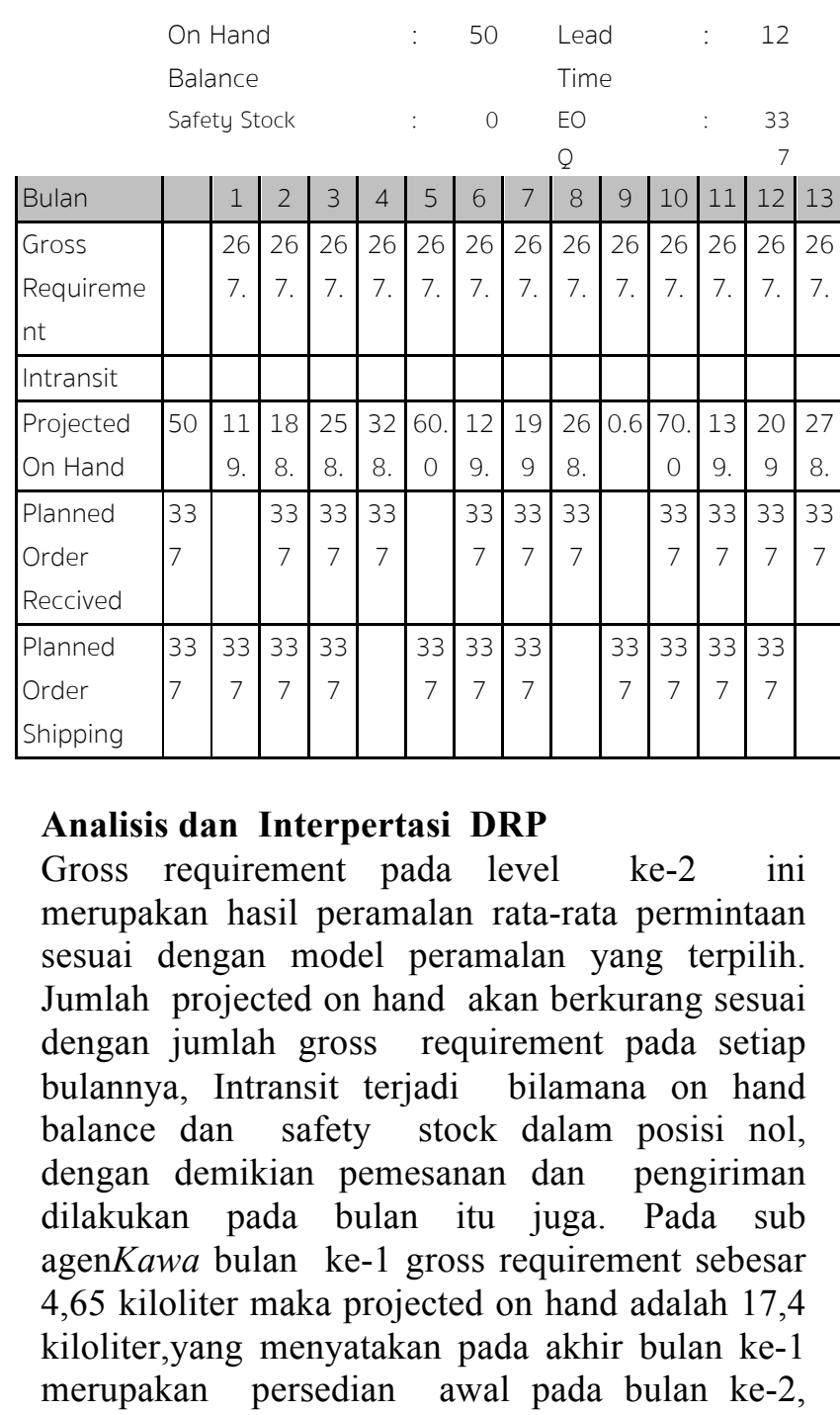

projected on hand pada bulan ke-2 adalah 12,7 kiloliter, yang menyatakan pada akhir bulan ke-3, projected on hand adalah 8.05 kiloliter, yang menyatakan pada bulan ke-3 merupakan persedian awal pada bulan ke-4 adalah 8.05 kiloliter, projected on hand adalah 3.4 kiloliter, yang menyatakan pada bulan ke-4 merupakan persedian awal pada bulan ke-5 adalah 3.4 kiloliter sendangkan gross requirement adalah 4,65 kiloliter sehingga terdapat kekurangan 1,25 kiloliter, untuk memenuhi kekurangan tersebut pemesanan harus datang pada bulan ke-5 jumlah sebanyak EOQ yaitu 22 kiloliter ini planned receipt . Karena tunggu waktu pemesanan dikurang dengan gross requirement, hal ini juga berlaku pada bulan berikutnya. Dengan demikian pembentukan DRP ini dilakukan mulai dari level yang terendah yaitu sub agen yang berhubungan langsung dengan konsumen, terus ke atas yakni agen,kemudian distributor dalam hal ini PT Linda.

\section{Penentuan Jadwal Induk Pemesanan dan Jadwal Pengiriman}

Jadwal induk pemesanan menyatakan kapan dan jumlah minyak solar yang harus disediakan oleh Linda. Jadwal induk pemesanan ini berasal dari bentuk DRP level nol pada planned order shipping pada setiap bulannya Setelah jadwal pemesanan dibuat maka selanjutnya dibuat jadwal pengiriman ${ }^{80}$ yang berisi kapan minyak solar harus dikirim ke 0 level dibawahnya untuk level 2 (sub agen) dan 33level 1 (agen).

Tabel 18. Jadwal Induk Pemesanan Minyak Solar

\begin{tabular}{|l|c|c|c|c|c|c|c|c|c|c|c|c|c|c|c|c|}
\hline Bulan & & 1 & 2 & 3 & 4 & 5 & 6 & 7 & 8 & 9 & 10 & 11 & 12 & 13 & 14 & 15 \\
\hline $\begin{array}{l}\text { Fotal } \\
\text { Pemesan }\end{array}$ & 33 & 33 & 33 & 33 & & 33 & 33 & 33 & & 33 & 33 & 33 & 33 & & 33 & \\
7 & 7 & 7 & 7 & & 7 & 7 & 7 & & 7 & 7 & 7 & 7 & & 7 & \\
\hline an & & & & & & & & & & & & & & & & \\
\hline
\end{tabular}

an

Tabel 20. Jadwal Pengiriman Minyak Solar

\begin{tabular}{|l|c|c|c|c|c|c|c|c|c|c|c|c|c|c|c|c|}
\hline Bulan & & 1 & 2 & 3 & 4 & 5 & 6 & 7 & 8 & 9 & 10 & 11 & 12 & 13 & 14 & 15 \\
\hline $\begin{array}{l}\text { Agen } \\
\text { Piru }\end{array}$ & 91 & 91 & & & $\begin{array}{c}11 \\
3\end{array}$ & & $\begin{array}{c}11 \\
3\end{array}$ & & 91 & & $\begin{array}{c}11 \\
3\end{array}$ & $\begin{array}{c}11 \\
3\end{array}$ & & & $\begin{array}{c}11 \\
3\end{array}$ \\
\hline $\begin{array}{l}\text { Agen } \\
\text { Kairatu }\end{array}$ & 33 & & & & 33 & 36 & & 33 & & & 36 & 33 & & & 33 & 36 \\
\hline $\begin{array}{l}\text { Agen } \\
\text { Saparua }\end{array}$ & 18 & & 18 & & 18 & & 18 & 33 & 18 & & & 18 & & 28 & & 18 \\
\hline $\begin{array}{l}\text { Agen } \\
\text { Taniwel }\end{array}$ & 97 & & & & 97 & & 97 & & 15 & 15 & 97 & & & 97 & & 97 \\
\hline $\begin{array}{l}\text { Total } \\
\text { Pengirim }\end{array}$ & 40 & 91 & 18 & & 42 & 36 & 39 & 66 & 29 & 15 & 24 & 21 & 11 & 38 & 33 & 42 \\
& 5 & & 8 & & 5 & & 1 & & 6 & 8 & 3 & 2 & & 8 \\
\hline
\end{tabular}




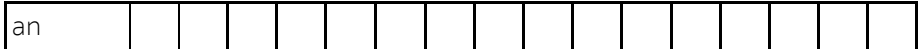

\section{PERHITUNGAN BIAYA OPERASIONAL DAN RUTE DISTRIBUSI YANG SEMENTARA DIJALANKAN.}

Perhitungan besarnya biaya operasional tergantung dari trayek distribusi yang dijalankan oleh Linda. Selama ini Linda dalam mendistribusikan minyak solar ke agan dan subagennya dengan trayek distribusi terbagi menjadi 2 Trayek antara lain :

\section{Untuk Trayek I.}

1. Kapal PT Linda dari pelabuhan Ambon (Gudang Arang) $\rightarrow$ Pelabuhan Saparua $\rightarrow$ Pelabuhan Kairatu $\rightarrow$ Pelabuhan Ambon (Gudang Arang)

Dimana biya operasi yang terjadi untuk trayek ini adalah :

a. Perhitungan Biaya operasional Kapal Berkala Prima Untuk Trayek I (Pelabuhan Ambon $\rightarrow$ Pelabuhan Saparua.

b. Perhitungan Biaya operasional Mobil tangki trayek I untuk Saparua $\rightarrow$ Tuhahah, Saparua $\rightarrow$ Nolot.

c. Perhitungan Biaya operasional Kapal Berkala Prima Untuk Trayek I (Pelabuhan Saparua $\rightarrow$ Pelabuhan Kairatu.

d. Perhitungan Biaya operasional Mobil tangki trayek I untuk Kairatu $\rightarrow$ Kamariang, Kairatu $\rightarrow$ Rumakai.

e. Perhitungan Biaya operasional Kapal Berkala Prima Untuk Trayek I (Pelabuhan Kairatu $\rightarrow$ Pelabuhan Ambon (Gudang Arang).

\section{Untuk Trayek II}

1. Kapal PT Linda dari pelabuhan Ambon (Gudang Arang) $\rightarrow$ Pelabuhan Piru $\rightarrow$ Pelabuhan Taniwel $\rightarrow$ Pelabuhan Ambon (Gudang Arang)

Dimana biya operasi yang terjadi untuk trayek ini adalah :

a. Perhitungan Biaya operasional Kapal Berkala Prima Untuk Trayek I (Pelabuhan Ambon $\rightarrow$ Pelabuhan Piru).

b. Perhitungan Biaya operasional Mobil tangki trayek II untuk Piru $\rightarrow$ Kawa, Piru $\rightarrow$ Pohon Batu.

c. Perhitungan Biaya operasional Kapal Berkala Prima Untuk Trayek II (Pelabuhan Piru Pelabuhan Taniwel. d. Perhitungan Biaya operasional Mobil tangki trayek II untuk Taniwel $\rightarrow$ Mornateng, Taniwel $\rightarrow$ Lisabata.

e. Perhitungan Biaya operasional Kapal Berkala Prima Untuk Trayek I (Pelabuhan Taniwel $\rightarrow$ Pelabuhan Ambon (Gudang Arang).

Selain biaya-biaya yang telah diuraikan diatas maka juga terdapat biaya tetap operasional antara lain :

a. Biaya makan untuk $17 \mathrm{ABK} /$

b. Biaya air tawar

c. Gaji Pegawai per bulan

d. Biaya telepon per bulan

e. Biaya keamanan per bulan

Dengan mengacu pada hasil perhitungan diatas maka total biaya operasional distribusi minyak solar per bulan Rp.19.896.250.- dan bila dikonversikan dalam tahun maka besarnya adalah Rp.19.896.250 x $12=$ Rp.238.755.000.-

\section{PERHITUNGAN BIAYA OPERASIONAL DAN RUTE DISTRIBUSI YANG DIUSULKAN.

Perhitungan Biaya Operasional Yang
Diusulkan.

Perhitungan besarnya biaya operasional tergantung dari trayek permintaan pendistribusian minyak solar yang dikelompokan dalam besarnya permintaan tiap agen PT linda.

\section{Untuk Trayek I.}

Untuk permintaan pendistribusian minyak solar per dua bulan sekali pesan yaitu untuk agen Saparua dan Piru.

1. Kapal Berkala Prima dari pelabuhan Ambon (Gudang Arang) $\rightarrow$ Pelabuhan Saparua $\rightarrow$ Pelabuhan Piru $\rightarrow$ Pelabuhan Ambon (Gudang Arang)

Dimana biya operasi yang terjadi untuk trayek ini adalah :

a. Perhitungan Biaya operasional Kapal Berkala Prima Untuk Trayek I (Pelabuhan Ambon $\rightarrow$ Pelabuhan Saparua.

b. Perhitungan Biaya operasional Mobil tangki trayek I untuk Saparua $\rightarrow$ Tuhahah, Saparua $\rightarrow$ Nolot.

c. Perhitungan Biaya operasional Kapal Berkala Prima Untuk Trayek I Pelabuhan Saparua $\rightarrow$ Pelabuhan Piru.

d. Perhitungan Biaya operasional Kapal Berkala Prima Untuk Trayek I (Pelabuhan Piru $\rightarrow$ Pelabuhan Ambon). 
e. perhitungan Biaya operasional Mobil tangki trayek II untuk Piru $\rightarrow$ Kawa, Piru $\rightarrow$ Pohon Batu.

Untuk Trayek II.

Untuk permintaan pendistribusian minyak solar per tiga bulan sekali pesan yaitu untuk agen Kairatu dan Taniwel.

1. Kapal Berkala Prima dari pelabuhan Ambon (Gudang Arang) $\rightarrow$ Pelabuhan Kairatu $\rightarrow$

Pelabuhan Taniwel $\rightarrow$ Pelabuhan Ambon (Gudang Arang)

Dimana biya operasi yang terjadi untuk trayek ini adalah :

a. Perhitungan Biaya operasional Kapal Berkala Prima Untuk Trayek I (Pelabuhan Ambon $\rightarrow$ Pelabuhan Kairatu.

b. Perhitungan Biaya operasional Mobil tangki trayek I untuk Kairatu $\rightarrow$ Kamariang, Kairatu $\rightarrow$ Rumakai.

c. Perhitungan Biaya operasional Kapal Berkala Prima Untuk Trayek II Pelabuhan Kairatu $\rightarrow$ Pelabuhan Taniwel.

d. Perhitungan Biaya operasional Mobil tangki trayek II untuk Taniwel $\rightarrow$ Mornateng, Taniwel $\rightarrow$ Lisabata.

e. Perhitungan Biaya operasional Kapal Berkala Prima Untuk Trayek II (Pelabuhan Taniwel $\rightarrow$ Pelabuhan Ambon).

Selain biaya-biaya yang telah diuraikan diatas maka juga terdapat biaya tetap operasional antara lain :
a. Biaya makan untuk $17 \mathrm{ABK}$
b. Biaya air tawar.
c. Gaji Pegawai per bulan.
d. Biaya telepon per bulan.
e. Biaya keamanan per bulan

Dengan mengacu pada hasil perhitungan diatas maka total biaya operasional jalur distribusi minyak solar yang lama sebesar Rp. 423.733.812,50 per tahun. sementara itu besar biaya operasional jalur distribusi minyak solar yang diusulkan sebesar Rp.159.524.420.- Per tahun. Dengan demikian maka akan terjadi pengehematan biaya operasional apabila perusahaan menggunakan jalur distribusi yang diusulkan, dengan besarnya biaya penghematan tersebut sebesar Rp.264.209.392.50 per tahun atau sebear $62,35 \%$ per tahun.

\section{KESIMPULAN}

Kesimpulan yang dapat diambil dari analisis diatas adalah sebagai berikut
1. Dengan mengunakan analisis DRP dapat diketahui jedwal pemesanan minyak dari pada agen - agen yang terdapat dalam level 2 .

2. Dengan mengunakan analisis DRP dapat diketahui jedwal pengiriman minyak solar pada agen - agen dan distributor PT Linda dalam mengsuplai minyak solar pada agenagen yang terdapat dalam level 2. Adapun jumlah yang harus dikirim untuk masingmasing agen antara lain ; agen Piru sebesar 273 kiloliter/tahun dengan 2 bulan per satu kali pengiriman, agen Kairatu sebesar 273 Kiloliter/tahun dengan 3 bulan per satu kali pengiriman, agen Saparua sebesar 1.613 Kiloliter/tahun dengan 2 bulan per satu kali pengiriman, agen Taniwel sebesar 612 Kiloloiter/tahun dengan 3 bulan per satu kali pengiriman.

3. Besar biaya distribusi selama periode perencanaan meliputi ; biaya Ordering Cost sebesar Rp. 12.409.153,-/tahun Biaya Holding Cost sebesar Rp.35.750.000.-/tahun

4. Dari analisa dengan mengunakan DRP maka dengan mengunakan jalur distribusi minyak solar yang diusulkan akan diperoleh biaya operasional sebesar Rp.159.524.420.- Per tahun. Dengan demikian maka akan terjadi pengehematan biaya operasional apabila perusahaan menggunakan jalur distribusi yang diusulkan, dengan besarnya biaya penghematan tersebut sebesar Rp.264.209.392.50 per tahun atau sebear $62,35 \%$ per tahun.

\section{SARAN}

Diharapkan adanya penelitian lanjutan dengan metode DRP Resource untuk mengkaji permasalahan yang lebih kompleks khususnya menyangkut keterbatasan sumber daya yang ada, baik berupa kapasitas kapal, modal, gudang, tenaga kerja dan lain-lain yang berupa probabilistik (misalnya menyangkut perubahanperubahan kondisi alam dalam proses pendistribusian).

\section{DAFTAR PUSTAKA}

Abas Salim H.A (1993), Manajemen Trasnportasi, Raja Grafindo Persada, Jakarta. Biegel J. E, (1980), Perencanaan dan Pengendalian Produksi,PHI, New Delhi.

Ballou R. H, (1992), Bisness Logistics Management, Third edition, Vase Westerve Reserve University, America. 
Buffa E. S, (1996), Manajemen Operasi dan Produksi Moderen, Binapura Angkasa, Jakarta.

Browersox D. J, (1986) Manajemen Logistik I dan 2,Bumi Aksara.

Billy J. Camerling, (2008), Model Perencanaan Kebutuhan Distribusi dan Rute Pengiriman Dengan Menggunakan Metode DRP (Distribution Requirements Planning) Pada Industri Jasa Penyalur Minyak Solar, Jurnal IlmiahArika, Media Ilmuan \& Praktisi Teknik Industri ISSN 1978-1105 Vol.1No.1 pp.14-24.

Dimyati T. T dan Dimyati A , (1992), operations Reserch, Sinar Baru, Bandung.

Gitosudarmo I. H, (1998), Manajemen Bisnis Logistik, Gajah Mada, Yogyakarta.

Handoko. H. T. Dkk, (1995), Dasar-Dasar Operasi Risearch, GPFE Yogyakarta

Nasution A H, (1999) Perencanaan dan Pengendalian Produksi, Guna Widya, Surabaya.

Rangkuti. F. (1998), Manajemen Persediaan, PT. Raja Grafindo Persada

Supranto J, (1984), Aplikasi dan Teori Statistik jilit 2, Erlangga, Jakarta.

Syafaruddin A, (1995). Alat-Alat Analisa Pembelanjaan, Edisi Revisi, Andi Offset Yogyakarta.

Tahan H. A, (1996), Riset Operasi Jilit II, Binarupa Aksara, Jakarta.
Wheelwright S. C. and McGee V. E, (1993) Metode dan Aplikasi Peramalan,Erlangga.

Wignjosoebroto S, (1993), Pengantar Teknik Industri, Guna Widya, Jakarta.

Paillin, D. B dan Sosebeko I, 2017 Penentuan Rute Optimal Distribusi Produk Nestle dengan Metode TSP. Jurnal ARIKA, Vol 11 No. 1. Pp.31-40

Marcus Tukan, Transportasi Kepulauan Dalam Mendukung Tol Laut, Polimedia Publishing Jakarta-Indonesia, ISBN : 978-602-6372-116., tahun 2017

J. Titarsole dan B. camerling (2017), Analisis Sisitm Antiam pada Area Parkir Mobil Tangki ke Filling Shed Dengan Menggunakan Promodel (Studi Kasus di Pt Pertamina Terminal BBM Wayame ambon),Jurnal IlmiahArika, Media Ilmuan \& Praktisi Teknik Industri ISSN 1978-1105 Vol.11 Pebruari.. 